\title{
Splice Variant-Specific Interaction of the NMDA Receptor Subunit NR1 with Neuronal Intermediate Filaments
}

\author{
Michael D. Ehlers, Eric T. Fung, Richard J. O'Brien, and Richard L. Huganir \\ Department of Neuroscience, Howard Hughes Medical Institute, The Johns Hopkins University School of Medicine, \\ Baltimore, Maryland 21205
}

\begin{abstract}
NMDA receptors are excitatory neurotransmitter receptors critical for synaptic plasticity and neuronal development in the mammalian brain. These receptors are found highly concentrated in the postsynaptic membrane of glutamatergic synapses. To investigate the molecular mechanisms underlying NMDA receptor localization, we used the yeast two-hybrid system to identify proteins expressed in the brain that interact with the NMDA receptor subunit NR1. Here we report that the $68 \mathrm{kDa}$ neurofilament subunit NF-L directly interacts with the NR1 subunit. This interaction occurs between the cytoplasmic C-terminal domain of NR1 and the rod domain of NF-L. However, NR1 splice variants lacking the first C-terminal exon cassette (C1) failed to associate with NF-L. Immunogold electron
\end{abstract}

microscopy revealed a preferential localization of NR1 at the ends of in vitro-assembled neurofilaments. Overexpression of C1 cassette-containing NR1 constructs in fibroblast cells disrupted the assembly of recombinant neurofilaments. In addition, NR1 and NF-L cofractionated in detergent-treated rat brain synaptic plasma membranes. Furthermore, NR1 and NF-L colocalize in the dendrites and growth cones of cultured hippocampal neurons. These results demonstrate the splice variant-specific association of NR1 with neurofilaments and suggest a possible mechanism for anchoring or localizing NMDA receptors in the neuronal plasma membrane.

Key words: NMDA receptor; NR1 subunit; C terminus; neurofilament; synaptic plasticity; splice variant
NMDA receptors constitute a major subclass of glutamate receptors in the mammalian brain (Seeburg, 1993; Hollmann and Heinemann, 1994; Mori and Mishina, 1995). These receptors play a crucial role in synaptogenesis, synaptic plasticity, and excitotoxicity (Constantine-Paton et al., 1990; Bliss and Collingridge, 1993; Choi, 1995). NMDA receptors are multimeric complexes formed from members of two families of homologous subunits, NR1 and NR2A-D (Moriyoshi et al., 1991; Kutsuwada et al., 1992; Meguro et al., 1992; Monyer et al., 1992; Mori and Mishina, 1995). Alternative splicing of NR1 mRNA provides additional molecular diversity, with eight different NR1 splice variants (NR1aNR1h) being expressed in the brain (Durand et al., 1992; Sugihara et al., 1992; Hollmann et al., 1993; Mori and Mishina, 1995). These NR1 splice variants, which arise via the insertion or deletion of three short exon cassettes in the N-terminal (N1) and C-terminal (C1, C2) domains of the NR1 molecule, differ in their spatial and temporal expression patterns (Laurie and Seeburg, 1994), their pharmacological properties (Durand et al., 1992; Hollmann et al., 1993; Traynelis et al., 1995), their ability to be phosphorylated by protein kinases (Tingley et al., 1993), their subcellular localization in transfected fibroblasts (Ehlers et al., 1995), and their responsiveness to calmodulin-mediated inactivation (Ehlers et al., 1996b).

The anchoring of neurotransmitter receptors to the cytoskeleton is a central feature of synaptic specialization (Froehner, 1993;

Received Aug. 28, 1997; revised Oct. 20, 1997; accepted Oct. 24, 1997.

This work was supported by the Medical Scientist Training Program (M.D.E. and E.T.F.). We thank J. Troncoso, P. Coulombe, and M. Lee for helpf ul discussions, M. Delannoy for assistance with electron microscopy, and C. Finch for help in preparing this manuscript.

Correspondence should be addressed to Dr. Richard L. Huganir, Howard Hughes Medical Institute, Department of Neuroscience, 725 North Wolfe Street, 904A PCTB, Baltimore, MD 21205.

Copyright (C) 1998 Society for Neuroscience $\quad 0270-6474 / 98 / 180720-11 \$ 05.00 / 0$
Ehlers et al., 1996a). Association with the cytoskeleton plays an important role in synaptogenesis and synaptic plasticity by regulating the distribution and density of neurotransmitter receptors (Froehner, 1993; Ehlers et al., 1996a). Like nicotinic acetylcholine receptors (nAChRs) at the neuromuscular junction (NMJ), NMDA receptors in the mammalian CNS are concentrated at synaptic sites where they are thought to be linked to cytoskeletal elements (Jones and Baughman, 1991; Huntley et al., 1994; Petralia et al., 1994a,b; Kornau et al., 1995; Ehlers et al., 1996a; Lau et al., 1996). However, the molecular basis for NMDA receptor clustering at the synapse remains primarily unknown.

Previous studies suggest that NMDA receptors directly or indirectly interact with the neuronal cytoskeleton. For example, NMDA receptor responses are sensitive to cytoskeletal strain (Paoletti and Ascher, 1994), and actin filament stabilization prevents $\mathrm{Ca}^{2+}$-dependent desensitization of NMDA channels (Rosenmund and Westbrook, 1993). Moreover, NMDA receptor subunits are found in the postsynaptic density (PSD), a structure enriched in cytoskeletal proteins (Kennedy, 1993; Harris and Kater, 1994; Moon et al., 1994). Recent findings also demonstrate that the $\mathrm{C}$ termini of certain NR2 subunits interact with members of the SAP90/PSD-95 family of synapse-associated proteins (SAPs) (Kornau et al., 1995; Lau et al., 1995; Niethammer et al., 1996). This interaction has been suggested to cross-link NMDA receptors to one another within the plasma membrane (PM) or to link NMDA receptors to cytoskeletal proteins or cytoplasmic signaling molecules (Gomperts, 1996). Additional studies have shown that the alternatively spliced $\mathrm{C} 1$ exon cassette directs the spontaneous aggregation of NR1 subunits in transfected fibroblast cells (Ehlers et al., 1995).

This study demonstrates that the NMDA receptor NR1 subunit interacts directly with the $68 \mathrm{kDa}$ neurofilament (NF) subunit NF-L in a manner regulated by alternative splicing. This 
interaction is shown to occur between the cytoplasmic C-terminal tail of NR1 and the rod domain of NF-L. The association of NR1 with NF-L requires the presence of the alternatively spliced $\mathrm{C} 1$ exon cassette in the NR1 subunit. The C terminus of NR1 is further shown to associate preferentially with the ends of assembled NFs. In addition, overexpression of NR1 constructs inhibits the assembly of heterologously expressed NFs. Interestingly, NR1 and NF-L protein cofractionate in detergent-treated rat synaptic membranes and colocalize in the dendrites and growth cones of cultured hippocampal neurons. Our results identify NF-L as a neuronal cytoskeletal element capable of directly binding to and anchoring NMDA receptors.

\section{MATERIALS AND METHODS}

Screening for NR1-interacting proteins using the yeast two-hybrid system. The yeast strain Y190 was kindly provided by Dr. Steve Elledge (Baylor University). The C-terminal domains of NR1a and NR1c from putative transmembrane domain 4 to the $\mathrm{C}$ terminus (amino acids 834-938 and 834-901, respectively) were PCR amplified from cDNA using the sense primer 5'-GATCATGATGCTAGCGAGATCGCCTACAAGCGAC-3' and the antisense primer 5'-GCTCATGATACTAGTAGCTCTCCCTATGACGGGAACACAG-3'. The amplified PCR products were then subcloned into the SalI and SpeI sites of the yeast expression vector pPC97. This placed the C-terminal NR1 constructs in-frame with the DNA binding domain of the GAL4 transcriptional activator. A cDNA library was made from adult rat hippocampus using the Superscript cDNA library synthesis kit (GIBCO) and was subcloned into the yeast expression vector pPC86 (library was kindly provided by Drs. A. Lanahan and P. Worley). This process fused hippocampal cDNAs with the activation domain of GAL4. Transformation of yeast with the NR1 $\mathrm{C}$-terminal clones was performed using the lithium acetate and polyethylene glycol (PEG) method (Ausubel et al., 1995). Transformation of the cDNA library, empty pPC86 vector, NFL-1-pPC86, or NFL-2-pPC86 into yeast expressing the NR1a- or NR1c-GAL4 binding domain was performed using a variation of the lithium acetate and PEG method. Briefly, yeast was grown to an optical density at $600 \mathrm{~nm}\left(\mathrm{OD}_{600}\right)$ of $\sim 1.0$, pelleted, and washed with water. The yeast was then incubated in $100 \mathrm{~mm}$ lithium acetate, $10 \mathrm{~mm}$ Tris, $\mathrm{pH}$ 7.5, $1 \mathrm{~mm}$ EDTA, and $1 \mathrm{~m}$ sorbital (LiSorb) at $30^{\circ} \mathrm{C}$ for $30 \mathrm{~min}$, pelleted, and resuspended in $2.5 \mathrm{ml}$ of LiSorb. To this, $50 \mu \mathrm{g}$ of library plus $800 \mu \mathrm{g}$ of carrier DNA in a final volume of $3 \mathrm{ml}$ of LiSorb were added, followed by $24 \mathrm{ml}$ of $100 \mathrm{~mm}$ lithium acetate, $10 \mathrm{~mm}$ Tris, $\mathrm{pH}$ 7.5, 1 mM EDTA, and 40\% PEG. Yeast was incubated for $30 \mathrm{~min}$ at $30^{\circ} \mathrm{C}$ and then for $15 \mathrm{~min}$ at $42^{\circ} \mathrm{C}$. One hundred milliliters of $\mathrm{Leu}^{-} \mathrm{Trp}^{-} \mathrm{His}^{-}$medium were added, and yeast was incubated for $3 \mathrm{hr}$ at $30^{\circ} \mathrm{C}$. Yeast was pelleted, resuspended in $\mathrm{Leu}^{-} \mathrm{Trp}^{-} \mathrm{His}^{-}$medium, plated on $\mathrm{Leu}^{-} \mathrm{Trp}^{-} \mathrm{His}{ }^{-}$plates containing $50 \mathrm{~mm} 3$-aminotriazole, and incubated at $30^{\circ} \mathrm{C}$. Colonies were restreaked and tested for activation of lacZ. Plasmids were isolated from yeast using glass beads, transformed into bacteria, and sequenced.

Construction, expression, and purification of NR1 and NF-L fusion proteins. The DNA sequences encoding the C-terminal regions of NR1a and NR1c were PCR amplified from cDNA using the sense primer $5^{\prime}$ ACCATGGATCCCGAGATCGCCTACAAGCGACAC-3' and the antisense primer $5^{\prime}$-ACCATGAATTCCTCAGCTCTCCCTATGACGGGAAC-3'. For construction of the NFL-1 fusion protein, the entire NFL-1 insert was PCR amplified from the NFL-1-pPC86 vector using the sense primer 5'-ACCATGGATCCTGAAGATACCCCACCAAACC-3' and the antisense primer 5'-ACCATGAATTCCTCATGAGCTCGACGTCTTACTTAC- $3^{\prime}$ corresponding to flanking vector sequences. PCR products were then subcloned into the BamHI and EcoRI sites of the bacterial expression vector pTrcHisB (Invitrogen, San Diego, CA). Plasmids with inserts were then transformed into the BL21 Escherichia coli strain. For expression of recombinant fusion protein, BL21 cells containing appropriate plasmids were grown in the presence of $75 \mu \mathrm{g} / \mathrm{ml}$ carbenicillin to an $\mathrm{OD}_{600}$ of $0.4-0.5$, at which time fusion protein expression was induced with $0.5 \mathrm{~mm}$ isopropyl- $\beta$-D-thiogalactopyranoside for $4 \mathrm{hr}$. Purification of expressed fusion protein was performed according to the manufacturer's instructions (Invitrogen). Briefly, bacteria were pelleted, were solubilized in $6 \mathrm{~m}$ guanidinium buffer containing $20 \mathrm{~mm}$ sodium phosphate, $\mathrm{pH} 7.8$, and $500 \mathrm{mM} \mathrm{NaCl}$, and were incubated with $\mathrm{Ni}^{+}$-agarose affinity resin (Qiagen, Hilden, Germany). The affinity resin, with bound hexahistidine fusion proteins, was washed 4 times with binding buffer $(8 \mathrm{M}$ urea, $20 \mathrm{~mm}$ sodium phosphate, $\mathrm{pH} 7.8$, and $500 \mathrm{~mm} \mathrm{NaCl})$ and 3 times with wash buffer $(8 \mathrm{M}$ urea, $20 \mathrm{~mm}$ sodium phosphate, $\mathrm{pH} 6.0$, and $500 \mathrm{~mm} \mathrm{NaCl}$ ). Bound proteins were then eluted with elution buffer ( $8 \mathrm{M}$ urea, $20 \mathrm{~mm}$ sodium phosphate, $\mathrm{pH} 4.0$, and $500 \mathrm{~mm} \mathrm{NaCl}$ ) and dialyzed against PBS.

$N R 1$ and NF-L cosedimentation assays. Ten micrograms each of NR1a and NR1c hexahistidine-tagged $\mathrm{C}$-terminal fusion proteins were incubated in the presence or absence of $100 \mu \mathrm{g}$ of purified NF-L in $1 \mathrm{ml}$ of a buffer containing $6 \mathrm{M}$ urea, $0.5 \%$ Nonidet P-40 (Sigma, St. Louis, MO), 25 mm sodium phosphate, pH 7.5, 1 mm EGTA, and $1 \mathrm{~mm}$ DTT. NF-L purified from bovine spinal cord was kindly provided by Dr. Juan Troncoso. Protein solutions were then dialyzed overnight at $37^{\circ} \mathrm{C}$ against a buffer containing $100 \mathrm{~mm}$ MES, pH 6.7, $170 \mathrm{~mm} \mathrm{NaCl,} 0.5$ mм EGTA, and $1 \mathrm{~mm}$ DTT to remove the urea and allow for neurofilament assembly. Dialyzed samples were then spun at $150,000 \times g$ for $60 \mathrm{~min}$ at $20^{\circ} \mathrm{C}$. Pellets were washed once with PBS and then solubilized in protein sample buffer. Proteins present in the supernatant were precipitated using trichloroacetic acid; the pellets were washed with acetone and then solubilized in protein sample buffer. Samples were then boiled, resolved by SDS-PAGE, and visualized by Coomassie blue staining.

Cell culture and transfections. QT6 or SW13 cells (kindly provided by Dr. P. Coulombe) were transfected with gene constructs for NF-L and NF-M subcloned into an expression vector containing the MSV promoter (kindly provided by Dr. M. Lee) and with the cDNAs for NR1a, NR1c, myc-NR1a-C terminus (Cterm), and myc-NR1c-Cterm were subcloned into an expression vector containing the cytomegalovirus promoter $(20$ $\mu \mathrm{g}$ of DNA/100 mm plate; $2 \mu \mathrm{g}$ of DNA per well in two-chambered glass chamber slides; Nunc, Naperville, IL) using calcium phosphate coprecipitation as described (Ehlers et al., 1995). QT6 cells were grown in Media 199 (GIBCO) supplemented with 10\% tryptose phosphate broth, $5 \%$ fetal bovine serum, and 1\% dimethylsulfoxide. SW13 cells were grown in DMEM/F-12 (GIBCO) supplemented with 5\% fetal bovine serum. Approximately $40-48 \mathrm{hr}$ after transfection, the cells were processed for immunofluorescent staining or solubilized for biochemical analysis.

Precipitation of NR1 subunits with NF-L fusion proteins. QT6 cells expressing either NR1a or NR1c were solubilized in 1\% SDS in buffer A [50 mm Tris-HCl, pH 7.4, 150 mm NaCl, 0.5 mm EGTA, 0.5 mm EDTA, $100 \mu \mathrm{M}$ phenylmethylsulfonylfluoride (PMSF) (Sigma), $10 \mu \mathrm{g} / \mathrm{ml}$ chymostatin (Chemicon, Temecula, CA), $10 \mu \mathrm{g} / \mathrm{ml}$ leupeptin (Chemicon), and $10 \mathrm{U} / \mathrm{ml}$ aprotinin (Miles, Elkhart, IN)], and the resulting cell lysate was diluted with 5 vol of $1 \%$ Triton X-100 in buffer A. The diluted cell lysates were sonicated on ice for $20 \mathrm{sec}$ and spun at $15,000 \times g$ for $15 \mathrm{~min}$ at $4^{\circ} \mathrm{C}$ to remove insoluble material. Soluble supernatants were precleared with $\mathrm{Ni}^{+}$-agarose (200 $\mu \mathrm{l}$ of a $1: 1$ slurry) for $40 \mathrm{~min}$ at $4^{\circ} \mathrm{C}$, and the precleared lysates then were incubated with either hexahistidine backbone fusion protein $(6 \mathrm{xHisBB})$ or NFL-1 fusion protein (NFL-1 6xHis) along with $\mathrm{Ni}^{+}$-agarose $(100 \mu \mathrm{l}$ of a $1: 1$ slurry; $2.5 \mathrm{mg}$ of protein $/ \mathrm{ml}$ of bed volume) for $2 \mathrm{hr}$ at $4^{\circ} \mathrm{C}$. Precipitated proteins were washed 5 times with buffer A plus $1 \%$ Triton $\mathrm{X}-100$, eluted with sample buffer, resolved by SDSPAGE, transferred to a polyvinylidene fluoride (PVDF) membrane (Immobilin-P; Millipore, Bedford, MA), and visualized by immunoblot analysis with enhanced chemiluminescence (ECL) detection. Immunoblots were performed as described previously (Ehlers et al., 1996b) using an affinity-purified anti-NR1 polyclonal antibody at 1:300 dilution (Tingley et al., 1993).

Immunogold electron microscopy. Neurofilaments were assembled from purified NF-L subunits $(50 \mu \mathrm{g})$ as described above in the presence or absence of $5 \mu \mathrm{g}$ of NR1a C-terminal fusion protein by dialysis overnight at $37^{\circ} \mathrm{C}$ against a buffer containing $100 \mathrm{~mm} \mathrm{MES,} \mathrm{pH} \mathrm{6.5,} 170 \mathrm{~mm} \mathrm{NaCl}$, $0.5 \mathrm{~mm}$ EGTA, and $1 \mathrm{~mm}$ DTT. Assembled neurofilaments were diluted 1:100 in PBS and then adsorbed onto copper grids (400 mesh; Pelco) for 2 min. Immediately before neurofilament adsorption, copper grids were freshly coated with a $50 \mathrm{~nm}$ thin layer of collodion (from $1 \%$ parlodion in amyl acetate), stabilized with carbon in a Polaron evaporator, and glow discharged for $15 \mathrm{sec}$. All subsequent rinses and incubations were done by grid flotation on $50 \mu \mathrm{l}$ drops of solution at room temperature. All solutions were filtered with a $0.22 \mu \mathrm{m}$ Gelman filter except for antibodycontaining solutions that were unfiltered. Grids were transferred between drops with a \#5 miracle-tip EM forceps (SPI) that was rinsed with distilled water and wiped dry with lint-free lens paper (Ross) between each step.

After neurofilament adsorption, grids were rinsed in PBS for $1 \mathrm{~min}$ and blocked in 5\% goat serum for $10 \mathrm{~min}$. After three 1 min rinses in PBS, grids were incubated for 30 min either with anti-NR1 antibody diluted 1:50 in PBS or with control preimmune serum in PBS. Grids were then 
rinsed 3 times for $1 \mathrm{~min}$ in PBS and were incubated for 30 min with $6 \mathrm{~nm}$ gold particle-conjugated donkey anti-rabbit IgG (Jackson ImmunoResearch, West Grove, PA) diluted 1:250 in PBS. Stained samples were then rinsed twice for $1 \mathrm{~min}$ in PBS and twice for $1 \mathrm{~min}$ in distilled water, followed by negative staining for 1 min with filtered $1 \%$ aqueous uranyl acetate (Pella) containing 0.2\% Tylose. Grids were then blotted on Whatman No. 1 filter paper and dried overnight before viewing on a Zeiss $10 \mathrm{~A}$ TEM operating at $100 \mathrm{kV}$. For quantitation of anti-NR1 immunolabeling, all gold particles present along clearly identifiable neurofilaments on $101.4 \times 1.8 \mu \mathrm{m}$ fields $(140,000 \times)$ visualized by $\mathrm{EM}$ on samples of NF-L filaments assembled in the presence of NR1a C-terminal fusion protein (as described above) were counted (a total of $3296 \mathrm{~nm}$ gold particles). The distance of each gold particle from the apparent end of the filament was then measured. For measurement of average filament length, two $1.4 \times 1.8 \mu \mathrm{m}$ fields from four separate experiments were used. Only clearly identified NFs contained completely within the field were measured.

Immunofluorescent microscopy. Transfected QT6 cells were rinsed 3 times with PBS, fixed for $15 \mathrm{~min}$ at room temperature (RT) with $4 \%$ paraformaldehyde in PBS containing $4 \%$ sucrose, and permeabilized for $6 \mathrm{~min}$ at $-20^{\circ} \mathrm{C}$ with methanol. Fixed cells were then blocked for $1 \mathrm{hr}$ at $37^{\circ} \mathrm{C}$ with $10 \%$ goat serum in PBS, incubated for $1 \mathrm{hr}$ at RT with primary antibodies in PBS containing 3\% goat serum, and incubated for $1 \mathrm{hr}$ at RT with secondary antibodies in PBS containing $3 \%$ goat serum. For neuronal immunocytochemistry, hippocampi from postnatal day 4 rats were dissociated with papain and grown at low density ( 40 neurons $/ \mathrm{mm}^{2}$ ) on a feeder layer of spinal cord glia. The medium was $75 \% \mathrm{MEM}, 25 \%$ neurobasal medium (GIBCO) plus N2 supplements (Banker and Goslin, 1991), $2 \%$ horse serum, and $15 \mu \mathrm{g} / \mathrm{ml}$ chick leg extract. After day 10 in vitro, cultures were fixed for $30 \mathrm{~min}$ in PBS with $4 \%$ paraformaldehyde and $4 \%$ sucrose, permeabilized for $5 \mathrm{~min}$ in $0.5 \%$ Triton X-100 in PBS, and blocked for $60 \mathrm{~min}$ at $30^{\circ} \mathrm{C}$ in $10 \%$ goat serum in PBS. Neurons were then incubated for $24 \mathrm{hr}$ at $4^{\circ} \mathrm{C}$ with anti-NR1 and anti-NF-L primary antibodies. Secondary antibodies were then added at $10 \mu \mathrm{g} / \mathrm{ml}$ for $1 \mathrm{hr}$. Labeled cells were mounted using PermaFluor aqueous mounting media (Immunon) with $20 \mathrm{mg} / \mathrm{ml}$ 1,4-diazabicyclo[2,2,2]-octane (Aldrich, Milwaukee, WI) and were visualized with a Zeiss Axiophot fluorescence microscope equipped with rhodamine and fluorescein optics. The primary antibodies used in these experiments were an affinity-purified rabbit antibody to NR1 (1:200 dilution) (Tingley et al., 1993), antineurofilament 68 monoclonal antibody clone NR4 (Sigma), and antivimentin monoclonal antibody clone VIM 13.2 (Sigma). The secondary antibodies used were rhodamine-conjugated donkey anti-rabbit IgG antibody, fluorescein isothiocyanate (FITC)-conjugated donkey anti-mouse IgG antibody, and FITC-conjugated donkey anti-mouse IgM antibody (Jackson ImmunoResearch).

Cofractionation of NF-L and NR1 from rat brain. Synaptic plasma membranes were prepared from rat brain in a manner similar to that described previously (Blackstone et al., 1992). All procedures were performed at $4^{\circ} \mathrm{C}$, and all solutions included $100 \mu \mathrm{M}$ PMSF and $20 \mathrm{U} / \mathrm{ml}$ aprotinin. Briefly, male Sprague Dawley rats (150-175 gm) were killed, and the cerebral cortices were immediately dissected out and homogenized in $10 \mathrm{vol}$ of HEPES-buffered sucrose (0.32 $\mathrm{m}$ sucrose, $4 \mathrm{~mm}$ HEPES, $\mathrm{pH}$ 7.4). The homogenate was centrifuged at $800 \times g$ for $10 \mathrm{~min}$, and the supernatant was centrifuged again at $9000 \times g$ for $15 \mathrm{~min}$. The pellet from the second centrifugation (the crude synaptosomal fraction) was resuspended in $10 \mathrm{vol}$ of HEPES-buffered sucrose and respun at $10,200 \times g$ for $15 \mathrm{~min}$. This pellet was lysed by hypo-osmotic shock in water, adjusted to $1 \mathrm{mM}$ HEPES, and incubated for $30 \mathrm{~min}$ with shaking. The lysate was then centrifuged at $25,000 \times g$ for $20 \mathrm{~min}$, the resulting pellet was resuspended in $4 \mathrm{~mm}$ HEPES, pH 7.4, with $0.25 \mathrm{M}$ sucrose, and the resuspended membranes were layered on the top of a discontinuous sucrose gradient $(0.8,1.0$, and $1.2 \mathrm{M}$ sucrose). Synaptic plasma membranes were recovered from the layer between 1.0 and $1.2 \mathrm{~m}$ sucrose and were resuspended in PBS. Isolated synaptic plasma membranes were further fractionated by solubilizing in either $2 \%$ SDS or $2 \%$ Triton $\mathrm{X}-100$ for $30 \mathrm{~min}$ at $4^{\circ} \mathrm{C}$ followed by centrifuging at $15,000 \times g$ for $15 \mathrm{~min}$ at $4^{\circ} \mathrm{C}$. Proteins present in the supernatants and pellets from the detergent solubilizations were taken up in sample buffer, resolved by SDS-PAGE, transferred to a PVDF membrane, and subjected to immunoblot analysis using either an anti-neurofilament 68 monoclonal antibody (Sigma) or an anti-NR1 polyclonal antibody. Immunoreactive bands were visualized by ECL.

\section{RESULTS}

\section{Interaction of NF-L with the C terminus of NR1}

The yeast two-hybrid system has been used previously to identify proteins that interact with NMDA receptor NR2 subunits (Kornau et al., 1995; Niethammer et al., 1996). To identify proteins that might be responsible for targeting or anchoring NR1 subunits, we used the C terminus of NR1a (amino acids 834-938) as a probe to identify clones encoding interacting proteins from a hippocampal cDNA library using the yeast two-hybrid system (Fig. 1A) (see Materials and Methods). Two separate screens were performed on a total of $2 \times 10^{6}$ clones, with three positive colonies identified. These three colonies represented two separate clones, each of which encoded portions of the $68 \mathrm{kDa}$ light neurofilament subunit (NF-L) (Fig. 1B) (Fuchs and Weber, 1994; Lee and Cleveland, 1994). The specificity of the interaction was verified by directly screening both NF-L clones and the NR1a C terminus against the corresponding yeast expression vector that lacks inserts (Fig. 1C,D). The first clone isolated corresponded to amino acids (aa) 77-364 of the full-length NF-L protein, whereas the second clone corresponded to aa 113-368 (Fig. $1 B$ ). The region common to these two clones (aa 113-364) lies within the rod domain, a domain that interacts with other neurofilament subunits and with other cytoskeletal proteins (Flynn et al., 1987; Frappier et al., 1991, 1992; Heins et al., 1993). Interestingly, although direct screening of NF-L against the NR1a C terminus indicated a strong interaction in yeast, NF-L did not interact with the $\mathrm{C}$ terminus of the NR1c splice variant of the NR1 protein (Fig. 1C,D). Because the only difference between $\mathrm{NR} 1 \mathrm{a}$ and NR1c is the presence of the C1 cassette in NR1a (Fig. $1 A$ ), these findings indicated that the $\mathrm{C} 1$ cassette was required for interaction with NF-L. However, the $\mathrm{C} 1$ cassette alone was not sufficient for interaction with NF-L in the yeast system (data not shown).

\section{Cosedimentation and coprecipitation of NR1 with NF-L are regulated by the $\mathrm{C} 1$ cassette}

To verify biochemically the interaction of NF-L with NR1, we performed cosedimentation assays using purified NF-L and bacterially expressed fusion proteins corresponding to the $\mathrm{C}$ termini of NR1a and NR1c (NR1a-Cterm and NR1c-Cterm) (see Materials and Methods) (Figs. $1 A, 2 A$ ). When incubated alone, both $\mathrm{C}$-terminal fusion proteins remained in the supernatant after a high-speed spin $(150,000 \times g)$ (Fig. $2 B)$. However, when incubated with purified NF-L, NR1a-Cterm was present primarily in the pellet along with assembled neurofilaments, whereas most of the NR1c-Cterm remained in the supernatant (Fig. 2B). NF-L was found almost exclusively in the sedimented pellet when incubated alone, and partial cosedimentation of NR1a-Cterm with NF-L occurred when NR1a-Cterm was added after NF assembly (data not shown). In addition, coprecipitation experiments performed on lysates of QT6 fibroblast cells expressing either full-length NR1a or NR1c subunits using a bacterially expressed fusion protein corresponding to aa 77-364 of NF-L (NFL-1 6xHis) showed that NR1a, but not NR1c, binds to this region of NF-L (Fig. 2C). No NR1 coprecipitated from mocktransfected cells (data not shown). These experiments provided additional evidence that the $\mathrm{C}$ terminus of NR1 interacts with the $68 \mathrm{kDa}$ neurofilament subunit and that the interaction is dependent on the $\mathrm{C} 1$ cassette. 
A

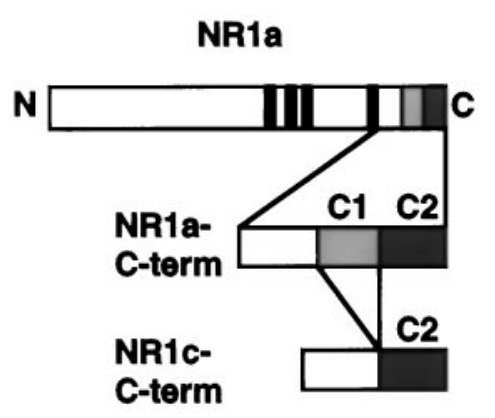

C

D

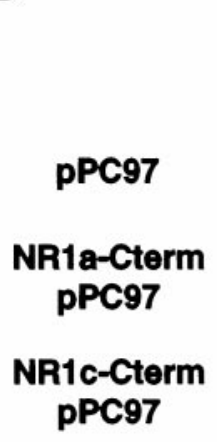

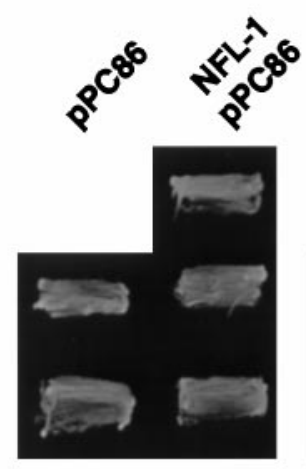

trp- lour
B

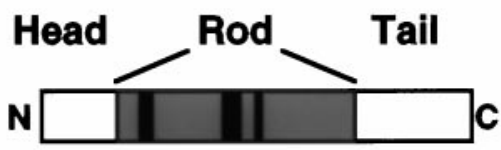

1A 1B 2A 2B
NFL-1

aa $77-364$

NFL-2

aa 113-368

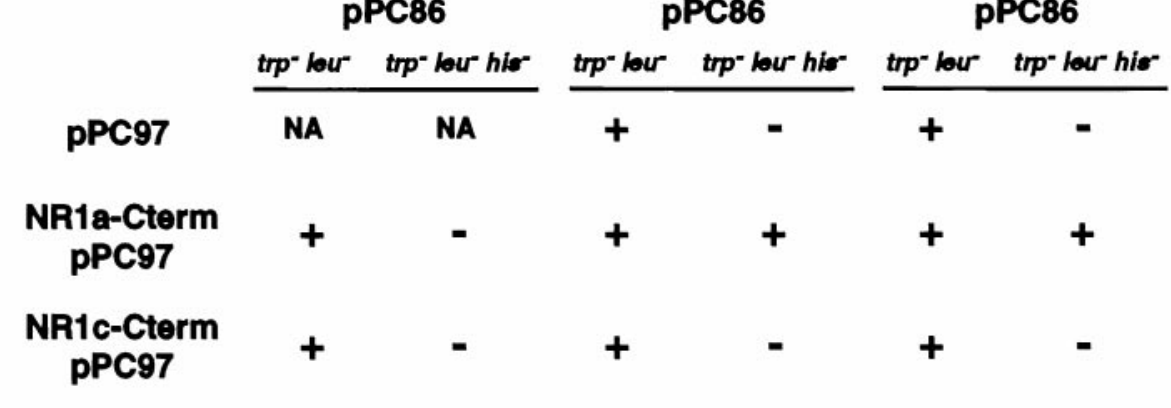

Figure 1. Identification of the encoding regions of hippocampal cDNA of NF-L that interact with the $\mathrm{C}$ terminus of the NR1a subunit. $A$, Schematic diagram of the NR1 subunit showing the alternatively spliced exon cassettes, $C 1$ and $C 2$, present in the C termini of the NR1a and NR1c splice variants (NR1a-Cterm and NR1c-Cterm, respectively). Narrow black boxes indicate the originally proposed four transmembrane domains. $B$, Domain structure of the $68 \mathrm{kDa}$ neurofilament subunit NF-L illustrating the head, rod, and tail domains of the molecule, as well as coils $1 A, 1 B, 2 A$, and $2 B$ (gray areas) within the rod domain. The regions of NF-L encoded by the isolated clones NFL-1 and NFL-2 (horizontal bars) are shown. C, Yeast (Y190) transformed with either pPC97 without insert, NR1a-Cterm pPC97, or NR1cCterm pPC97 in combination with either pPC86 without insert, NFL-1-pPC86, or NFL-2-pPC86 as indicated (see Materials and Methods). Transformed yeast was then assayed for growth on Trp ${ }^{-} \mathrm{Leu}^{-}$or $\mathrm{Trp}^{-} \mathrm{Leu}^{-} \mathrm{His}^{-}$plates; + indicates growth; - indicates no growth; and $N A$ indicates transformant combinations not assayed. $D$, Growth of yeast double transformants on Trp ${ }^{-} \mathrm{Leu}^{-}$(left) or $\mathrm{Trp}^{-} \mathrm{Leu}^{-} \mathrm{His}^{-}$(center) plates. Yeast colonies grown on $\operatorname{Trp}^{-} \mathrm{Leu}^{-} \mathrm{His}{ }^{-}$ plates were lifted onto nitrocellulose and assayed lacZ for $\beta$-galactosidase activity (right).

\section{NR1 preferentially interacts with the ends of assembled NFs}

To examine further the nature of the interaction between NR1 and NF-L, we performed immunogold electron microscopy on NFs assembled from purified NF-L subunits in the presence or absence of NR1a C-terminal fusion protein (Fig. 3). Gold particles, indicating NR1 immunoreactivity, were observed to associate closely with assembled filaments (Fig. 3A,B). No NR1 labeling was seen with NFs assembled in the absence of NR1 fusion protein (Fig. $3 C$ ) or with NFs assembled with NR1 fusion protein but stained with control serum (Fig. 3D). Interestingly, gold particles were observed most frequently at the ends of assembled NFs (Fig. 3A, B, arrowheads). In addition, NR1 immunoreactivity was sometimes associated with amorphous electron dense regions, perhaps representing truncated NFs (Fig. 3B, thin arrows). Quantitation of the distance of gold particles from the ends of
NF-L-containing filaments revealed that NR1 immunoreactivity was indeed found predominantly at the ends of filaments, at a median distance of $19.5 \mathrm{~nm}$ from the filament end (Fig. 4). The average length of NFs assembled in the presence of NR1a $\mathrm{C}$-terminal fusion protein under these conditions was $329 \pm 82$ nm $(n=4$; see Materials and Methods and below). These results indicated that NR1 interacts preferentially with the ends of NFs.

\section{NR1 inhibits NF assembly}

Preferential interaction of the NR1a C terminus with the ends of NFs suggested that NR1 binding might prevent further filament elongation. Measurement of the length of NFs assembled from purified NF-L subunits in the presence or absence of NR1a $\mathrm{C}$-terminal fusion protein (see Materials and Methods) indicated a decrease in average filament length from $532 \pm 93 \mathrm{~nm}$ to $329 \pm$ $82 \mathrm{~nm}(n=4)$. The relatively short nature of the NFs assembled 
A

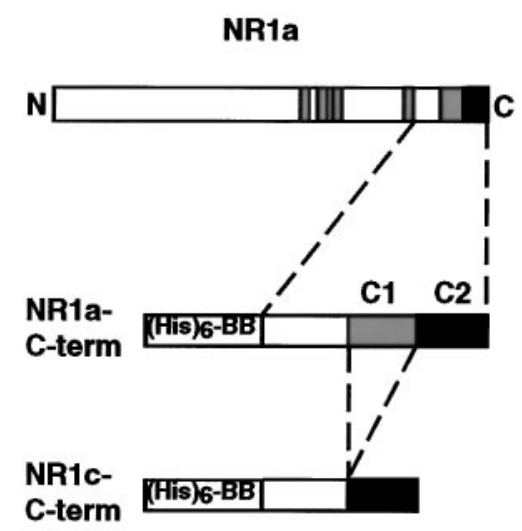

B

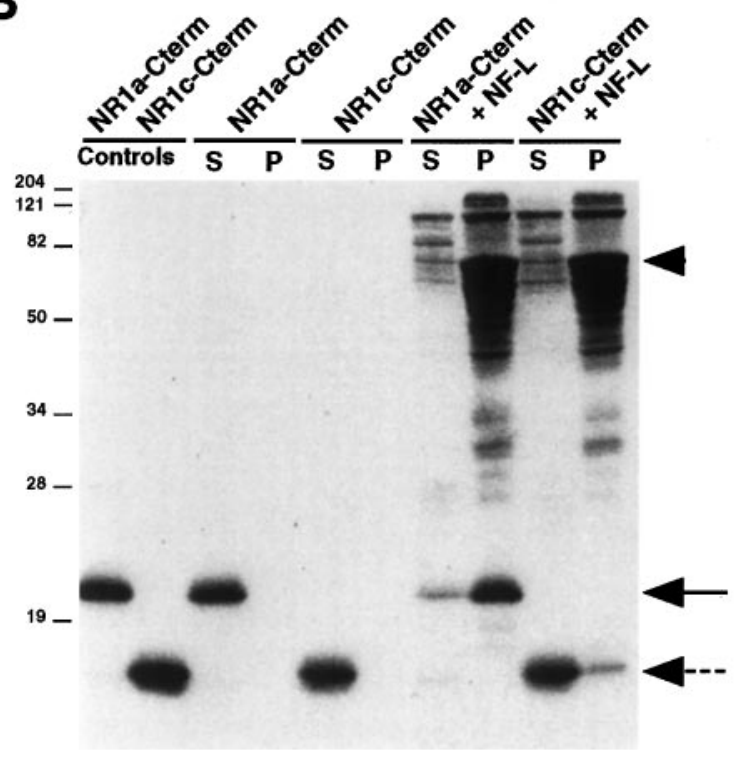

C

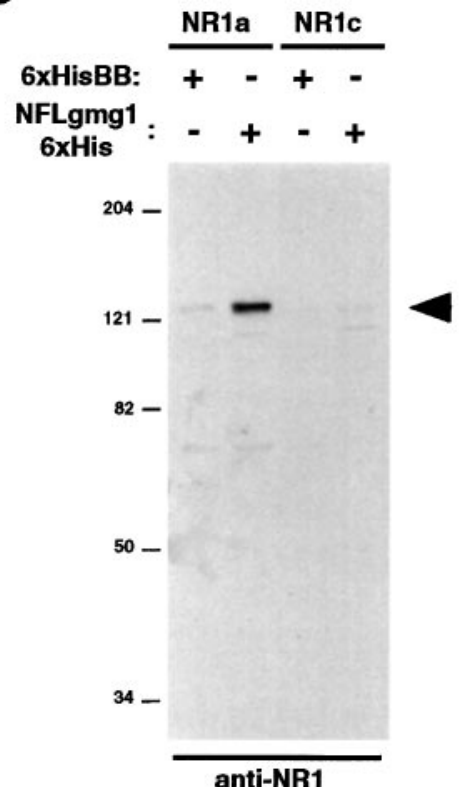

Figure 2. Interaction of NF-L with $\mathrm{C} 1$ cassette-containing NR1 splice variants. $A, B$, Ten micrograms of purified fusion protein corresponding to NR1a-Cterm or NR1c-Cterm were dissolved in $8 \mathrm{M}$ urea in the presence or absence of $100 \mu \mathrm{g}$ of purified NF-L and dialyzed against a buffer containing $100 \mathrm{~mm}$ MES, pH 6.5, $170 \mathrm{~mm} \mathrm{NaCl}, 1.0 \mathrm{~mm}$ DTT, and $0.5 \mathrm{~mm}$ EGTA (see Materials and Methods). Polymerized neurofilaments were then sedimented by centrifugation at $150,000 \times g$. Proteins present in the supernatants $(S)$ and pellets $(P)$ were resolved by SDS-PAGE and visualized by Coomassie blue staining. Ten micrograms each of NR1a-Cterm and NR1c-Cterm were run as controls (left two lanes). The arrowhead indicates NF-L, the solid arrow indicates NR1a-Cterm, and the dashed arrow indicates NR1c-Cterm. C, QT6 cells expressing either NR1a or NR1c were solubilized, and the cell lysates were incubated with either $6 \mathrm{xHisBB}$ or NFL-1 6xHis. Bound protein complexes were precipitated using $\mathrm{Ni}^{+}$-agarose, resolved by SDS-PAGE, and subjected to immunoblot analysis using an anti-NR1 antibody. The arrowhead indicates precipitated NR1 protein. In $B$ and $C$, molecular mass markers in kilodaltons are shown.

in these experiments was likely caused by use of a $\mathrm{pH}$ (6.7) higher than the optimal assembly $\mathrm{pH}$ (6.25) during filament assembly (Heins et al., 1993). The higher $\mathrm{pH}$ was required for NR1 and NF-L binding (data not shown). The requirement for a higher $\mathrm{pH}$ could be attributable to charge interactions between the two proteins, or alternatively it might result in more exposed rod domains in the "kinky" NFs.

To explore the effect of NR1 on NF assembly in intact cells, we performed immunofluorescent microscopy on QT6 fibroblast cells expressing NF-L and NF-M together with NR1a, NR1c, NR1a C terminus, or NR1c C terminus (Fig. 5). Expression of NF-L and NF-M resulted in the appearance of a filamentous NF network throughout the cell (Fig. $5 A$ ). Coexpression of NR1a with NF-L and NF-M resulted in a more diffuse NF-L staining pattern (Fig. $5 B$, left). In $>70 \%$ of NR1a, NF-L, and NF-M cotransfected cells, NF-L staining was absent from the cell periphery, and no filamentous staining was observed (Fig. 5B, left). However, coexpression of NR1c with NF-L and NF-M had no apparent effect on the formation of NFs (Fig. 5B, right). Similarly, recombinant NF-L and NF-M filaments failed to form in cells expressing the C-terminal tail of NR1a, with NF-L staining restricted to perinuclear areas in $>95 \%$ of the cells examined (Fig. 5C, left). In contrast, recombinant NFs readily formed and extended throughout cells expressing the NR1c C-terminal tail (Fig. 5C, right). Similar results were obtained in the intermediate filament ${ }^{-}\left(\mathrm{IF}^{-}\right)$human SW13 cell line, and transfection of NR1a or the C terminus of NR1a had little or no effect on endogenous vimentin networks in QT6 fibroblasts (data not shown; see Discussion). Overexpression of NF-L in QT6 cells had no effect on the $\mathrm{C} 1$ cassette-dependent clustering of the NR1 subunit reported previously (Ehlers et al., 1995). These experiments demonstrated that NR1 subunits and their cytoplasmic tails inhibit the assembly of NFs both in vitro and in intact cells and that this inhibition is dependent on the $\mathrm{C} 1$ cassette.

\section{Cofractionation of NR1 and NF-L from rat cortex}

NMDA receptor subunits are enriched in the PSD (Moon et al., 1994), a structure thought to contain molecules important in the clustering and anchoring of glutamate receptors (Kennedy, 1993; Harris and Kater, 1994; Ehlers et al., 1996a). To determine whether NF-L was present in biochemical fractions enriched for NR1, synaptic plasma membranes (SPMs) from rat cortex were isolated, fractionated by detergent solubilization, and examined for the presence of NF-L and NR1 (Fig. 6) (see Materials and Methods). Both NF-L and NR1 proteins were present in SPM preparations from rat cortex (Fig. $6 A, B$, right lanes). NF-L protein present in SPMs was insoluble in $2 \%$ Triton $\mathrm{X}-100$ but soluble in $2 \%$ SDS (Fig. $6 A$ ), a pattern also observed for the NR1 subunit (Fig. 6B). However, NR1 and NF-L failed to coimmunoprecipitate from rat SPMs, presumably because of the insolubility of NR1 and NF-L under nondenaturing conditions (data not shown). Although evidence of a direct interaction in brain is lacking, our findings show that both NR1 and NF-L cofractionate in detergent-extracted rat synaptic plasma membranes, consistent with an in vivo association between NR1 and NF-L.

\section{Colocalization of NR1 and NF-L in neuronal dendrites and growth cones}

Long, organized neurofilaments are major constituents of neuronal axons in which they are believed to play a role in axonal 

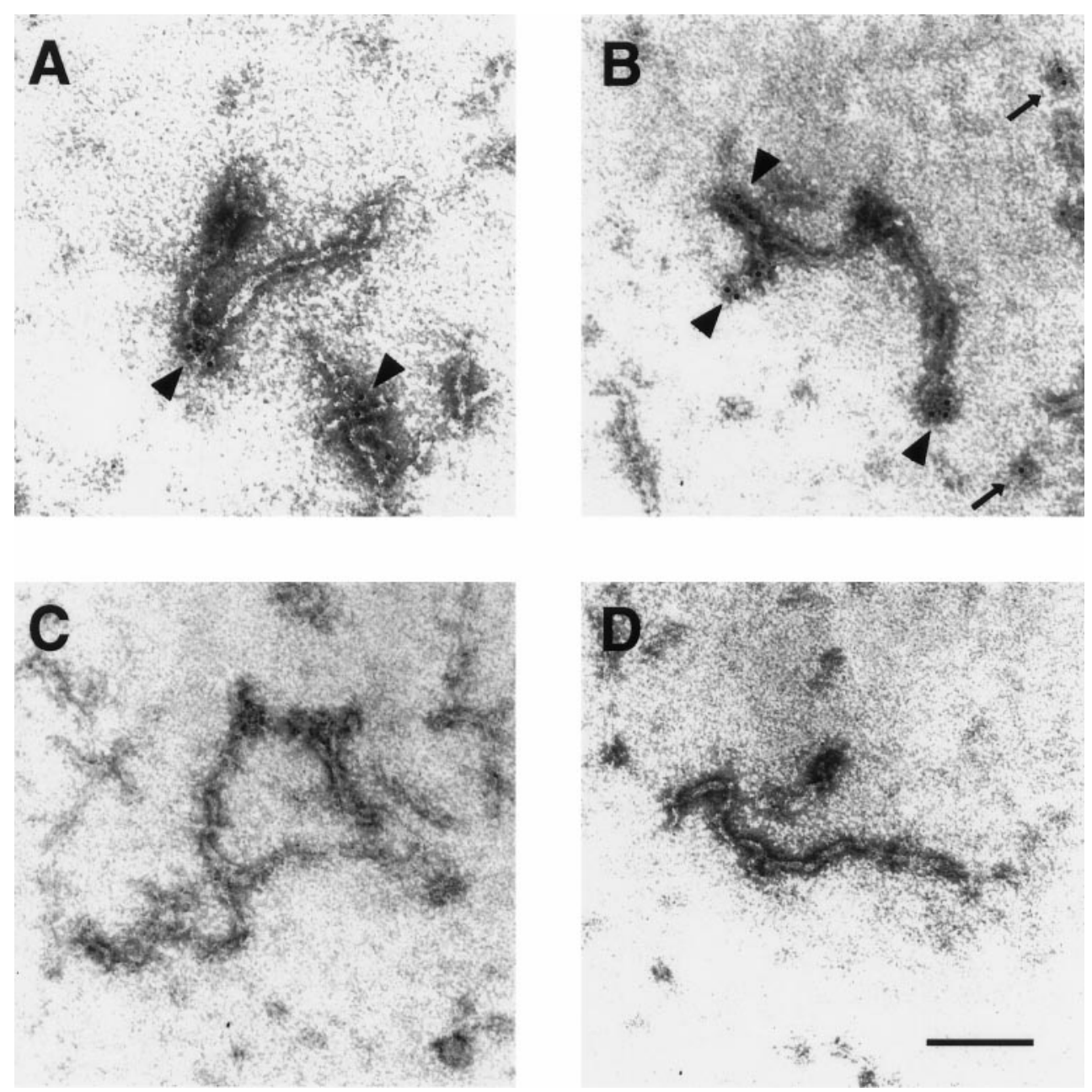

Figure 3. Localization of NR1 along assembled neurofilaments by immunogold electron microscopy. Purified NF-L was assembled in vitro in the presence $(A, B, D)$ or absence $(C)$ of NR1a C-terminal fusion protein (see Materials and Methods). Assembled filaments were adsorbed onto carbon-coated copper grids and stained with either anti-NR1 antibody $(A-C)$ or control antisera $(D)$ followed by goldconjugated secondary antibody $(6 \mathrm{~nm}$ gold particle). Labeled filaments were visualized by electron microscopy. Gold particles were observed at the ends of filaments $(A$, $B$, arrowheads) and sometimes over amorphous regions of electron density assumed to represent truncated filaments $(B$, thin arrows). Magnification, $224,000 \times$. Scale bar, $0.1 \mu \mathrm{m}$.

structure and caliber (Lee and Cleveland, 1994). In addition, neurofilaments are found in dendrites in which they are present in a much less-ordered array composed of shorter filaments (Peters et al., 1991; Benson et al., 1996). To examine whether NR1 and NF-L are present in similar subcellular locations within neurons, we performed immunofluorescent microscopy on cultured hippocampal neurons (Fig. 7). Although NF-L, but not NR1, was present in axons, both NR1 and NF-L were present in the cell bodies and dendrites of hippocampal neurons (Fig. $7 A-C$ ). Interestingly, NR1 staining, although absent from the axon proper, was enriched in the extending growth cones of hippocampal neurons in which it colocalized with intense NF-L staining (Fig. $7 D-F)$. The absence of NR1 subunits from the axon proper, a site of abundant NF-L protein, could be caused by the lack of free filament ends (and NF-L rod domains) in the highly ordered, lengthy axonal filaments (see Discussion). These findings indicated that both NR1 and NF-L are present in neuronal dendrites and growth cones, sites of possible interaction between these two proteins.

\section{DISCUSSION}

The mechanisms by which neurotransmitter receptors are anchored to the cytoskeleton differ between various receptors and are likely to involve all three major cytoskeletal elements. At spinal neuron inhibitory synapses, the clustering of glycine receptors is mediated via the indirect linkage of glycine receptor $\beta$-subunits to microtubules by the protein gephyrin (Kirsch et al.,
1993; Kirsch and Betz, 1995; Meyer et al., 1995). At the mammalian NMJ, nAChRs are closely associated with the $43 \mathrm{kDa}$ peripheral membrane protein rapsyn, a cytoskeletal protein required for nAChR clustering (Phillips et al., 1991; Maimone and Merlie, 1993; Gautam et al., 1995). Rapsyn may function by indirectly linking $\mathrm{nAChRs}$ to the actin cytoskeleton through the dystrophin-associated glycoprotein (DAG) complex (Apel et al., 1995) or by linking nAChRs to type III IFs (E. T. Fung and R. L. Huganir, unpublished observations).

Previous studies have suggested that IFs are involved in the organization of synapses. The IF protein desmin is highly concentrated at the vertebrate NMJ where it is found near the AChR-rich crests of the junctional folds (Sealock et al., 1989; Bilak et al., 1994). In addition neurofilaments, although most abundant in large myelinated axons (Lee and Cleveland, 1994), are also found in the dendrites and subplasmalemmal cortex of neurons (Peters et al., 1991; Braun et al., 1993). Moreover, NF subunits are found in preparations of the PSD from brain (Walsh and Kuruc, 1992; Harris and Kater, 1994), further suggesting a possible role in central synapse organization.

In this study we have shown that the cytoplasmic tail of the NMDA receptor NR1 subunit directly binds to and inhibits the assembly of NFs. NFs are the major intermediate filament in mature neurons (Fuchs and Weber, 1994). These filaments are formed from the three NF polypeptide subunits NF-L (68 kDa), NF-M (150 kDa), and NF-H (200 kDa) (Lee and Cleveland, 
Figure 4. Distribution histogram of NR1 immunolabeling along assembled neurofilaments. Quantitative gold particle counting was performed on NF-L-containing filaments assembled in the presence of NR1a C-terminal fusion proteins (see Materials and Methods). The number of gold particles found at a given distance from the end of identified neurofilaments is plotted. The median distance of gold particles from filament ends is indicated (arrowhead, $19.5 \mathrm{~nm}$ ). The average filament length was $329 \pm 82 \mathrm{~nm}(n=4)$.

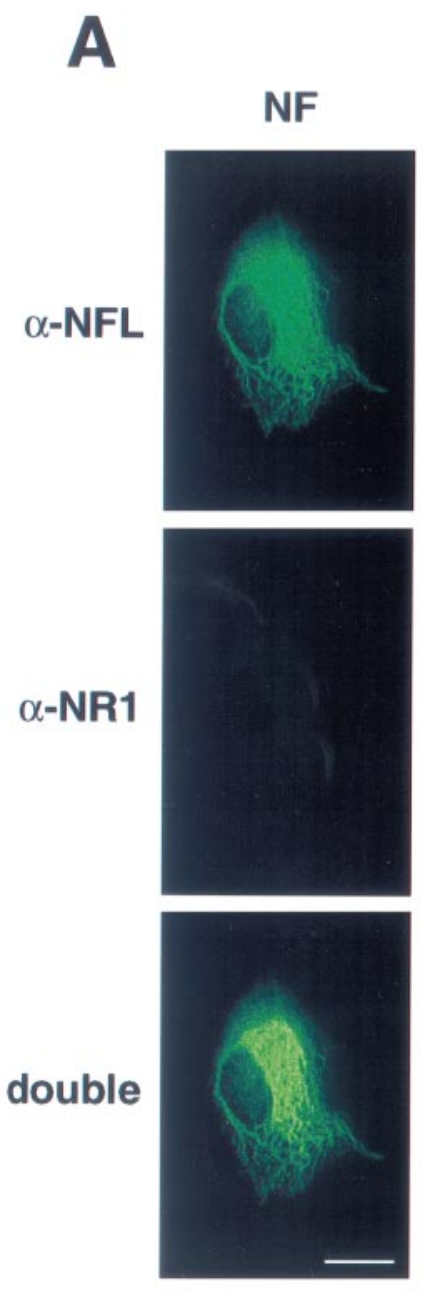

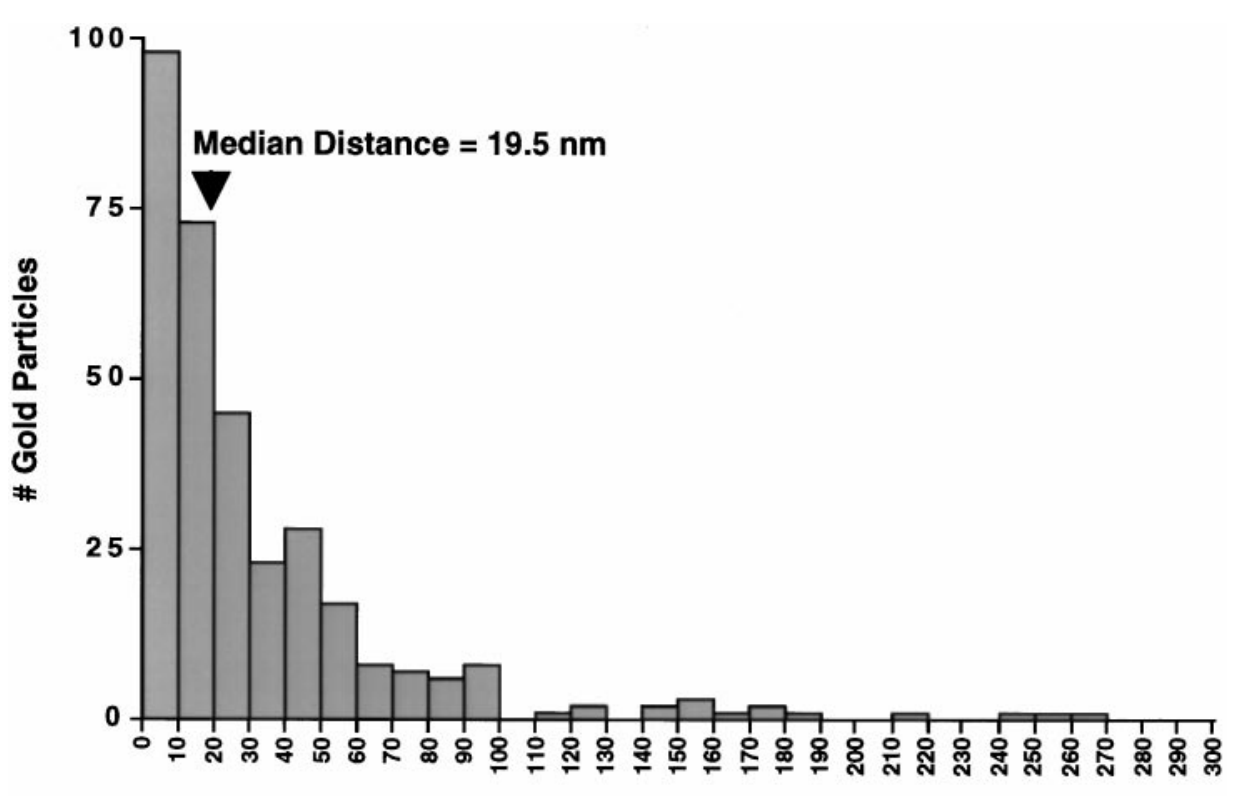

Distance from Filament End (nm)

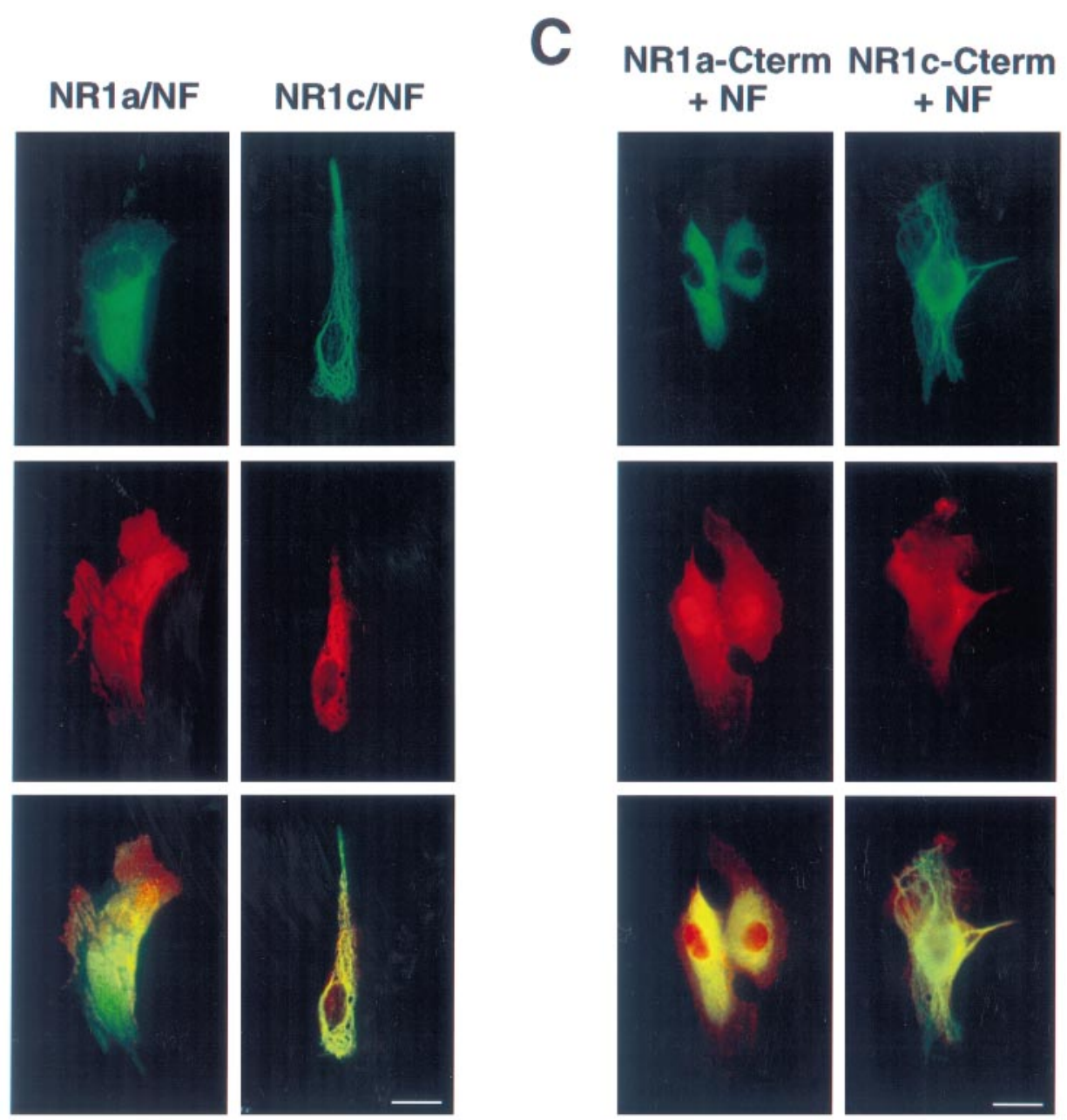

Figure 5. Expression of either full-length or C-terminal NR1a constructs disrupts the assembly of recombinant neurofilaments in fibroblast cells. QT6 cells were transiently cotransfected with combinations of expression vectors expressing either NF-L plus NF-M $(N F)(A)$ or NF-L plus NF-M along with either NR1a $(B$, left $)$, NR1c $(B$, right $)$, myc-tagged NR1a C terminus $(C$, left $)$, or myc-tagged NR1c C terminus $(C$, right $)$. Cells were fixed and stained with antibodies against NF-L $(A-C$, top; $\alpha-N F L)$ and NR1 $(A-C$, middle; $\alpha-N R 1)$ along with appropriate secondary antibodies conjugated with rhodamine $(A-C$, middle $)$ or FITC $(A-C$, top $)$ and visualized by immunofluorescent microscopy. Double exposures are shown at the bottom $(A-C)$. Scale bars, $10 \mu \mathrm{m}$. 
A

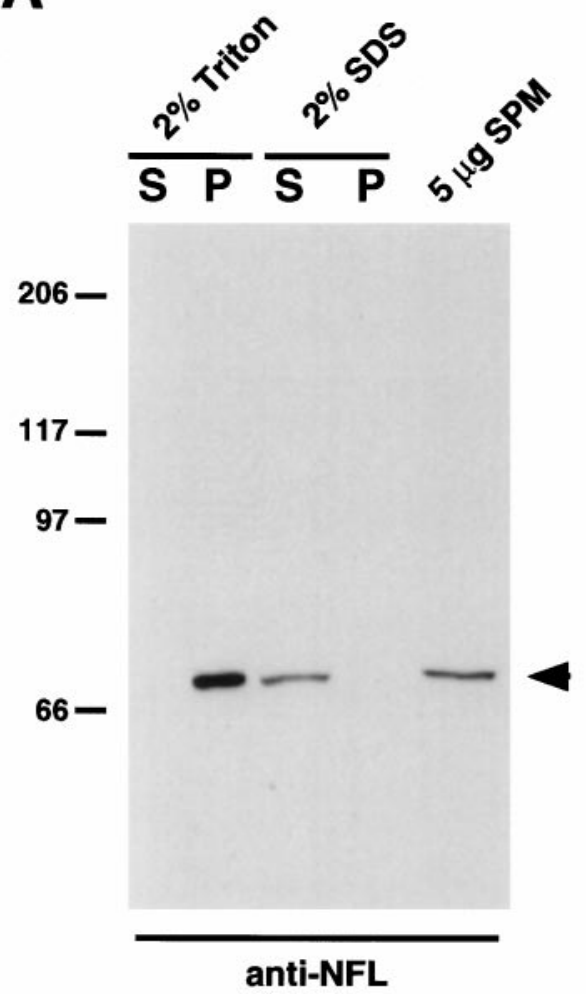

B
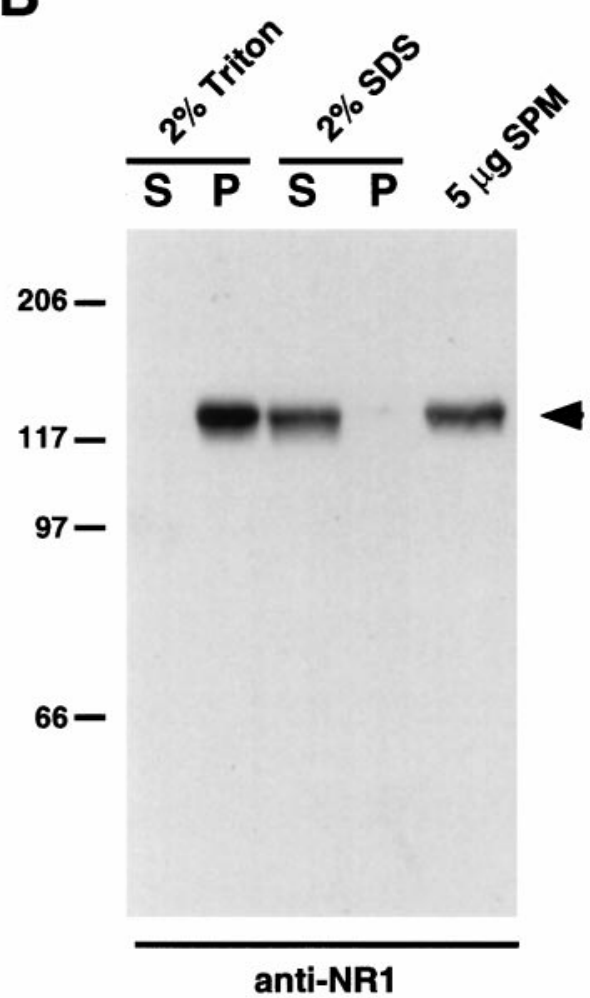

Figure 6. Cofractionation of NF-L and NR1 from rat brain. Synaptic plasma membranes isolated from rat brain $(5 \mu \mathrm{g})$ were solubilized in either $2 \%$ Triton X-100 or $2 \%$ SDS, and insoluble proteins were sedimented by centrifugation at $15,000 \times g$. Proteins present in the supernatants $(S)$ and pellets $(P)$ were resolved by SDSPAGE and subjected to immunoblot analysis using either an anti-NFL antibody $(A)$ or an anti-NR1 antibody $(B)$. Five micrograms of total synaptic plasma membranes were run as controls $(A, B$, right lanes $)$. Arrowheads indicate either NF-L protein $(A)$ or NR1 protein $(B)$. Molecular mass markers in kilodaltons are shown.
1994), which together assemble to form polymeric NFs. Among these subunits, NF-L is an obligatory subunit, which is capable of forming complete neurofilaments in the presence of substoichiometric amounts of NF-M or NF-H (Ching and Liem, 1993; Lee et al., 1993).

The binding of NR1 to NFs occurs through the rod domain of NF-L and requires the 37 aa alternatively spliced $\mathrm{C} 1$ cassette of NR1. The rod domain of NF-L is thought to regulate NF architecture and assembly via coiled-coil and interhelical ion pair interactions (Heins et al., 1993; Fuchs and Weber, 1994). In addition, the NF-L rod domain interacts with other cytoskeletal proteins, including brain $\beta$-spectrin and microtubule-associated protein-2 (MAP2) (Flynn et al., 1987; Frappier et al., 1991, 1992). Interestingly, the $\mathrm{C}$ terminus of NR1 has also recently been shown to interact with the rod domain of $\alpha$-actinin, a protein associated with the actin cytoskeleton (Wyszynski et al., 1997). The central rod domains of IFs are predicted to be buried within the filament interior, likely accessible only at the ends of filaments (Fuchs and Weber, 1994). Consistent with this are our findings (1) that the C terminus of NR1 preferentially interacts with the ends of assembled NF-L filaments in vitro (Figs. 3, 4) and (2) that NR1 colocalizes with NF-L at neuronal growth cones (Fig. 7), where neurofilament ends are presumably in abundance. Moreover, the observed inhibition of NF assembly by NR1 (Fig. 5) is also likely to be explained by a "capping" of the NF ends via the interaction of NR1 with the NF-L rod domain.

The attachment of IFs to the cell surface is important for the formation of a variety of specialized membrane structures (Jones and Green, 1991). In epithelial cells, IFs attach to the PM at desmosomes where they are linked to integral membrane desmosomal cadherins through cytoplasmic desmoplakins and plakoglobins (Stappenbeck and Green, 1992; Stappenbeck et al., 1993; Kouklis et al., 1994; Troyanovsky et al., 1994). In skeletal muscle, desmin-containing IFs extend to the sarcolemma at costameres, specialized structures thought to act as sites of force transmission (Pardo et al., 1983; Danowski et al., 1992). In cardiac myocytes, IFs interact with intercalated disks, desmosomal-like PM structures involved in mechanical and electrical coupling between cells, and with costameres as in skeletal muscle (Danowski et al., 1992; Small et al., 1992). In smooth muscle cells, desmincontaining IFs attach to the PM at dense subplasmalemmal zones referred to as attachment plaques, possibly by interacting with plectin or filamin/gyronemin (Small and Sobieszek, 1977; Small et al., 1986, 1992; Brown and Binder, 1992). Several lines of evidence also indicate a close association of IF with the cortical actin-based membrane skeleton. In fibroblasts, IFs impinge on the cytoplasmic face of focal contacts (Bershadsky et al., 1987), as well as with stress fibers near the cell substrate (Green et al., 1986). In addition, desmin, vimentin, and the light neurofilament subunit NF-L all associate with spectrin either directly (Langley and Cohen, 1986, 1987; Frappier et al., 1991, 1992) or indirectly through ankyrin (Georgatos and Marchesi, 1985; Georgatos et al., 1987). The present study adds to the growing list of IF-PM interactions by demonstrating a novel direct linkage between integral membrane NMDA receptor complexes and NFs.

The selective localization and insolubility of NMDA receptors in the brain have strongly suggested a cytoskeletal linkage of these receptors (Ehlers et al., 1996a). The interaction of NF-L with NMDA receptors could provide such a linkage by anchoring NMDA receptors in the PM to cytoplasmic NFs. NFs are most often considered because of their structural role in axons, particularly their role in specifying the axonal diameter of large myelinated axons (Lee and Cleveland, 1994). Although less abundant and less organized, NFs are also present in neuronal dendrites (Peters et al., 1991; Benson et al., 1996), where their function has remained much less certain. Interestingly, NF-L 


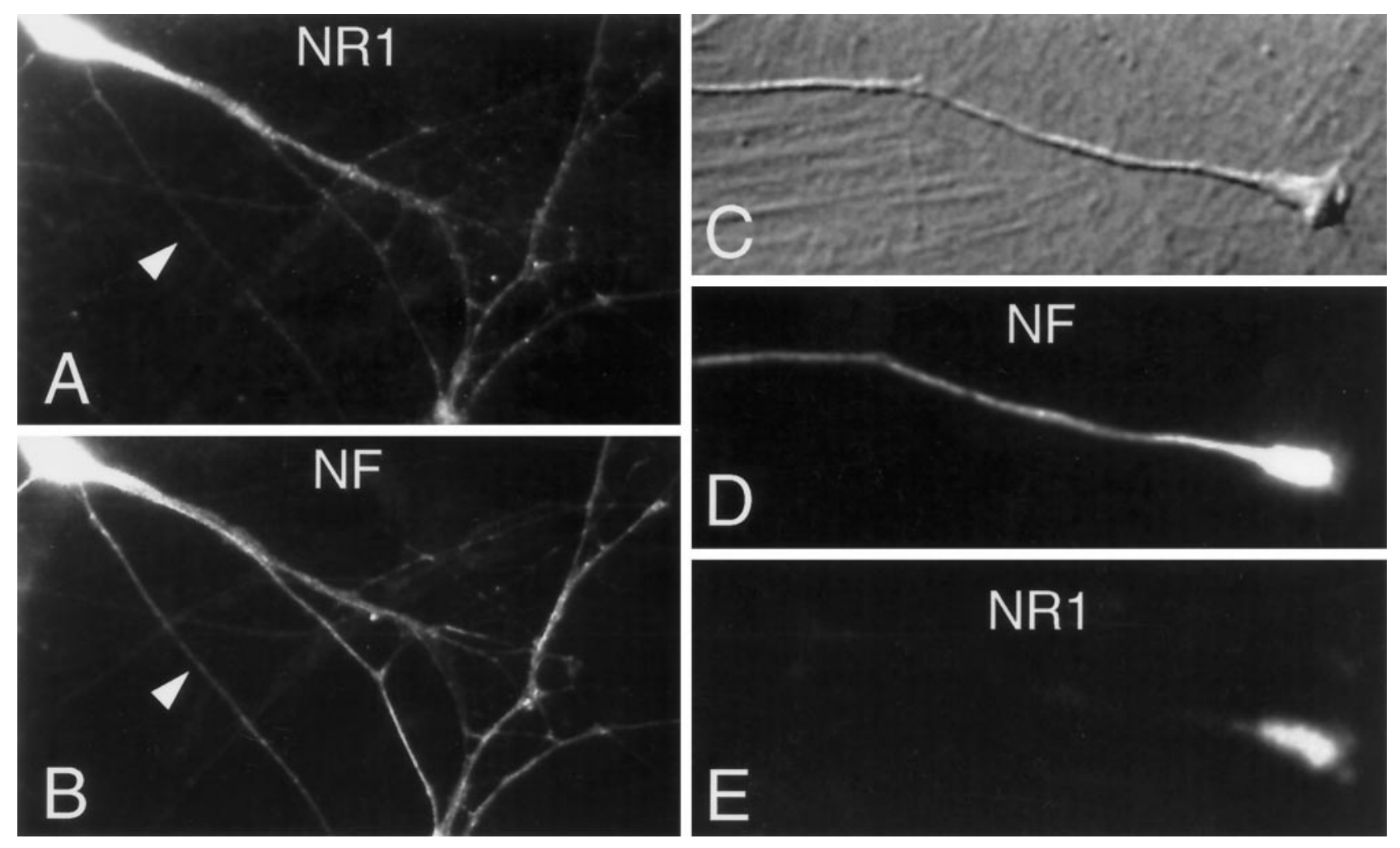

Figure 7. Cultured hippocampal neurons were fixed and stained for NR1 and neurofilament (NF) after $10 \mathrm{~d}$ in culture (see Materials and Methods). The dendritic processes of two neurons are shown to be diffusely stained for both NR1 $(A)$ and NF $(B)$, whereas an overlying axon (arrowhead in $A$, $B$ ) is stained only for NF. All NR1 staining was peptide blockable and was absent from the glial mat underlying these neurons. In $C-E$ a higher-power view of another axon, terminating in a growth cone, is displayed. NR1 staining is restricted to the growth cone, whereas NF stain extends throughout the axon as well as the growth cone.

interacts with MAP2, a protein restricted to dendrites (Flynn et al., 1987), and is also found in biochemical preparations of the PSD (Walsh and Kuruc, 1992; Harris and Kater, 1994). In addition, NR1 subunits and NF-L colocalize in neuronal dendrites and growth cones (Fig. 7). It is tempting to speculate that dendritic NFs might act, in part, to organize the subsynaptic cytoskeleton. Interaction of NR1 with NF-L might also explain the presence of $\mathrm{C} 1$ cassette-containing NR1 splice variants in presynaptic termini (Liu et al., 1994). Alternatively, interaction with NFs could anchor NMDA receptors to nonsynaptic PM sites, effectively sequestering these receptors away from the synapse until released by an appropriate intracellular signal.

The 37 aa $\mathrm{C} 1$ cassette is a highly basic stretch of amino acids that has been identified previously as a site of significant functional regulation of NMDA receptors. The $\mathrm{C} 1$ cassette serves as a substrate for phosphorylation by both protein kinase C (Tingley et al., 1993) and protein kinase A (Tingley et al., 1997). The C1 cassette also contains a high affinity calmodulin ( $\mathrm{CaM})$ binding site that can modulate CaM-dependent inactivation of NMDA receptors (Ehlers et al., 1996b). In addition, the C1 cassette targets recombinant NR1 subunits to receptor-rich domains in cultured cell lines (Ehlers et al., 1995) (see Fig. 5B, left, middle), presumably via a cytoskeletal association. In this study, we have shown that the highly basic $\mathrm{C} 1$ cassette is also required for interaction of the NR1 C-terminal tail with NF-L. Interestingly, clusters of basic amino acids in the IF binding protein plectin similar to those found in the $\mathrm{C} 1$ cassette are responsible for binding to and disrupting vimentin filaments (Nikolic et al., 1996), suggesting a similar mechanism of interaction.
The convergence of phosphorylation, CaM binding, and cytoskeletal association at the $\mathrm{C} 1$ cassette suggests that these three processes may regulate one another. Indeed, phosphorylation of serines contained within the $\mathrm{C} 1$ cassette rapidly disperses NR1rich domains in cultured QT6 fibroblasts (Ehlers et al., 1995), perhaps by disrupting the interaction of NR1 with QT6 IFs. Although expression of NR1a and the NR1a C terminus in QT6 cells had no apparent disruptive effect on endogenous QT6 cell vimentin networks, this could be because of the low turnover rate of endogenous vimentin filaments relative to heterologously expressed neurofilaments. It has been reported that the association of NMDA receptors with the cytoskeleton is $\mathrm{Ca}^{2+}$-sensitive (Rosenmund and Westbrook, 1993), perhaps because of the competitive binding of $\mathrm{Ca}^{2+}-\mathrm{CaM}$ and NF-L to the $\mathrm{C} 1$ cassette. Although in these studies cytoskeletal association was assessed by actin filament depolymerizing or stabilizing agents (Rosenmund and Westbrook, 1993), these compounds can also indirectly result in IF redistribution (Green et al., 1987). It will be important for future studies to address the role of protein phosphorylation and $\mathrm{CaM}$ binding in regulating the interaction between NR1 and NF-L as well as the distribution of NMDA receptors in neurons.

In summary, we have demonstrated a novel association between the NMDA receptor subunit NR1 and the $68 \mathrm{kDa}$ neurofilament subunit NF-L. This interaction is regulated by alternative splicing of the NR1 subunit, a mechanism known to affect the subcellular distribution of NR1 in cultured fibroblasts. Moreover, we have shown that NR1 preferentially binds to the ends of NFs, with overexpression of NR1 disrupting NF assembly. Furthermore, NR1 and NF-L are found enriched in identical fractions 
from rat brain synaptic plasma membranes and are localized to similar regions in cultured hippocampal neurons. These findings provide evidence of a cytoskeletal association of the NMDA receptor complex that may regulate its cellular distribution and functional properties in the brain. It will be important for future studies to determine whether additional cytoskeletal or intermediate filament proteins with homologous rod domains are also capable of interacting with the NMDA receptor complex.

\section{REFERENCES}

Apel ED, Roberds SL, Campbell KP, Merlie JP (1995) Rapsyn may function as a link between the acetylcholine receptor and the agrinbinding dystrophin-associated glycoprotein complex. Neuron 15:115-126.

Ausubel FM, Brnet R, Kingston RE, Moore DD, Seidman JG, Smith SA, Struhl K (1995) Analysis of protein interactions. In: Current protocols in molecular biology, pp 20.0.1-20.1.23. New York: Wiley.

Banker G, Goslin K (1991) Culturing nerve cells. Cambridge, MA: MIT.

Benson DL, Mandell JW, Shaw G, Banker G (1996) Compartmentation of alpha-internexin and neurofilament triplet proteins in cultured hippocampal neurons. J Neurocytol 25:181-196.

Bershadsky AD, Tint IS, Svitkina TM (1987) Association of intermediate filaments with vinculin-containing adhesion plaques of fibroblasts. Cell Motil Cytoskeleton 8:274-283.

Bilak M, Askanas V, Engel WK (1994) Alpha 1-antichymotrypsin is strongly immunolocalized at normal human and rat neuromuscular junctions. Synapse 16:280-283.

Blackstone CD, Moss SJ, Martin LJ, Levey AI, Price DL, Huganir RL (1992) Biochemical characterization and localization of a non- $N$ methyl-D-aspartate glutamate receptor in rat brain. J Neurochem $58: 1118-1126$.

Bliss TV, Collingridge GL (1993) A synaptic model of memory: longterm potentiation in the hippocampus. Nature 361:31-39.

Braun N, Schikorski T, Zimmermann H (1993) Cytoplasmic segregation and cytoskeletal organization in the electric catfish giant electromotoneuron with special reference to the axon hillock region. Neuroscience 52:745-756.

Brown KD, Binder LI (1992) Identification of the intermediate filamentassociated protein gyronemin as filamin. Implications for a novel mechanism of cytoskeletal interaction. J Cell Sci 102:19-30.

Ching GY, Liem RK (1993) Assembly of type IV neuronal intermediate filaments in nonneuronal cells in the absence of preexisting cytoplasmic intermediate filaments. J Cell Biol 122:1323-1335.

Choi DW (1995) Calcium: still center-stage in hypoxic-ischemic neuronal death. Trends Neurosci 18:58-60.

Constantine-Paton M, Cline HT, Debski E (1990) Patterned activity, synaptic convergence, and the NMDA receptor in developing visual pathways. Annu Rev Neurosci 13:129-154.

Danowski BA, Imanaka-Yoshida K, Sanger JM, Sanger JW (1992) Costameres are sites of force transmission to the substratum in adult rat cardiomyocytes. J Cell Biol 118:1411-1420.

Durand GM, Gregor P, Zheng X, Bennett MV, Uhl GR, Zukin RS (1992) Cloning of an apparent splice variant of the rat $N$-methyl-Daspartate receptor NMDAR1 with altered sensitivity to polyamines and activators of protein kinase C. Proc Natl Acad Sci USA 89:9359-9363.

Ehlers MD, Tingley WG, Huganir RL (1995) Regulated subcellular distribution of the NR1 subunit of the NMDA receptor. Science 269:1734-1737.

Ehlers MD, Mammen AL, Lau LF, Huganir RL (1996a) Synaptic targeting of glutamate receptors. Curr Opin Cell Biol 8:484-489.

Ehlers MD, Zhang S, Bernhadt JP, Huganir RL (1996b) Inactivation of NMDA receptors by direct interaction of calmodulin with the NR1 subunit. Cell 84:745-755.

Flynn G, Joly JC, Purich DL (1987) The 28,000 Mr microtubule-binding domain of microtubule-associated protein-2 also contains a neurofilament-binding site. Biochem Biophys Res Commun 148:1453-1459.

Frappier T, Stetzkowski-Marden F, Pradel LA (1991) Interaction domains of neurofilament light chain and brain spectrin. Biochem $\mathrm{J}$ 275:521-527.

Frappier T, Derancourt J, Pradel LA (1992) Actin and neurofilament binding domain of brain spectrin beta subunit. Eur $\mathrm{J}$ Biochem 205:85-91.

Froehner SC (1993) Regulation of ion channel distribution at synapses. Annu Rev Neurosci 16:347-368.

Fuchs E, Weber K (1994) Intermediate filaments: structure, dynamics, function, and disease. Annu Rev Biochem 63:345-382.

Gautam M, Noakes P, Mudd J, Nichol M, Chu G, Sanes J, Merlie J (1995) Failure of postsynaptic specialization to develop at neuromuscular junctions of rapsyn-deficient mice. Nature 377:232-236.

Georgatos SD, Marchesi VT (1985) The binding of vimentin to human erythrocyte membranes: a model system for the study of intermediate filament-membrane interactions. J Cell Biol 100:1955-1961.

Georgatos SD, Weber K, Geisler N, Blobel G (1987) Binding of two desmin derivatives to the plasma membrane and the nuclear envelope of avian erythrocytes: evidence for a conserved site-specificity in intermediate filament-membrane interactions. Proc Natl Acad Sci USA 84:6780-6784.

Gomperts SN (1996) Clustering membrane proteins: it's all coming together with the PSD-95/SAP90 protein family. Cell 84:659-662.

Green KJ, Talian JC, Goldman RD (1986) Relationship between intermediate filaments and microfilaments in cultured fibroblasts: evidence for common foci during cell spreading. Cell Motil Cytoskeleton 6:406-418.

Green KJ, Geiger B, Jones JC, Talian JC, Goldman RD (1987) The relationship between intermediate filaments and microfilaments before and during the formation of desmosomes and adherens-type junctions in mouse epidermal keratinocytes. J Cell Biol 104:1389-1402.

Harris KM, Kater SB (1994) Dendritic spines: cellular specializations imparting both stability and flexibility to synaptic function. Annu Rev Neurosci 17:341-371.

Heins S, Wong PC, Muller S, Goldie K, Cleveland DW, Aebi U (1993) The rod domain of NF-L determines neurofilament architecture, whereas the end domains specify filament assembly and network formation. J Cell Biol 123:1517-1533.

Hollmann M, Heinemann S (1994) Cloned glutamate receptors. Annu Rev Neurosci 17:31-108.

Hollmann M, Boulter J, Maron C, Beasley L, Sullivan J, Pecht G, Heinemann S (1993) Zinc potentiates agonist-induced currents at certain splice variants of the NMDA receptor. Neuron 10:943-954.

Huntley GW, Vickers JC, Janssen W, Brose N, Heinemann SF, Morrison JH (1994) Distribution and synaptic localization of immunocytochemically identified NMDA receptor subunit proteins in sensorymotor and visual cortices of monkey and human. J Neurosci 14:3603-3619.

Jones JC, Green KJ (1991) Intermediate filament-plasma membrane interactions. Curr Opin Cell Biol 3:127-132.

Jones KA, Baughman RW (1991) Both NMDA and non-NMDA subtypes of glutamate receptors are concentrated at synapses on cerebral cortical neurons in culture. Neuron 7:593-603.

Kennedy MB (1993) The postsynaptic density. Curr Opin Neurobiol 3:732-737.

Kirsch J, Betz H (1995) The postsynaptic localization of the glycine receptor-associated protein gephyrin is regulated by the cytoskeleton. J Neurosci 15:4148-4156.

Kirsch J, Wolters I, Triller A, Betz H (1993) Gephyrin antisense oligonucleotides prevent glycine receptor clustering in spinal neurons. Nature 366:745-748.

Kornau HC, Schenker LT, Kennedy MB, Seeburg PH (1995) Domain interaction between NMDA receptor subunits and the postsynaptic density protein PSD-95. Science 269:1737-1740.

Kouklis PD, Hutton E, Fuchs E (1994) Making a connection: direct binding between keratin intermediate filaments and desmosomal proteins. J Cell Biol 127:1049-1060.

Kutsuwada T, Kashiwabuchi N, Mori H, Sakimura K, Kushiya E, Araki K, Meguro H, Masaki H, Kumanishi T, Arakawa M (1992) Molecular diversity of the NMDA receptor channel. Nature 358:36-41.

Langley Jr RC, Cohen CM (1986) Association of spectrin with desmin intermediate filaments. J Cell Biochem 30:101-109.

Langley Jr RC, Cohen CM (1987) Cell type-specific association between two types of spectrin and two types of intermediate filaments. Cell Motil Cytoskeleton 8:165-173.

Lau LF, Huganir RL (1995) Differential tyrosine phosphorylation of $N$-methyl-D-aspartate receptor subunits. J Biol Chem 270:20036-20041.

Lau LF, Mammen A, Ehlers MD, Kindler S, Chung WJ, Garner CC, Huganir RL (1996) Interaction of the $N$-methyl-D-aspartate receptor 
complex with a novel synapse-associated protein, SAP102. J Biol Chem 271:21622-21628.

Laurie DJ, Seeburg PH (1994) Regional and developmental heterogeneity in splicing of the rat brain NMDAR1 mRNA. J Neurosci 14:3180-3194.

Lee MK, Cleveland DW (1994) Neurofilament function and dysfunction: involvement in axonal growth and neuronal disease. Curr Opin Cell Biol 6:34-40.

Lee MK, Xu Z, Wong PC, Cleveland DW (1993) Neurofilaments are obligate heteropolymers in vivo. J Cell Biol 122:1337-1350.

Liu H, Wang H, Sheng M, Jan LY, Jan YN, Basbaum AI (1994) Evidence for presynaptic $N$-methyl-D-aspartate autoreceptors in the spinal cord dorsal horn. Proc Natl Acad Sci USA 91:8383-8387.

Maimone MM, Merlie JP (1993) Interaction of the $43 \mathrm{kd}$ postsynaptic protein with all subunits of the muscle nicotinic acetylcholine receptor. Neuron 11:53-66.

Meguro H, Mori H, Araki K, Kushiya E, Kutsuwada T, Yamazaki M, Kumanishi T, Arakawa M, Sakimura K, Mishina M (1992) Functional characterization of a heteromeric NMDA receptor channel expressed from cloned cDNAs. Nature 357:70-74.

Meyer G, Kirsch J, Betz H, Langosch D (1995) Identification of a gephyrin binding motif on the glycine receptor beta subunit. Neuron 15:563-572.

Monyer H, Sprengel R, Schoepfer R, Herb A, Higuchi M, Lomeli H, Burnashev N, Sakmann B, Seeburg PH (1992) Heteromeric NMDA receptors: molecular and functional distinction of subtypes. Science 256:1217-1221.

Moon IS, Apperson ML, Kennedy MB (1994) The major tyrosinephosphorylated protein in the postsynaptic density fraction is $N$-methylD-aspartate receptor subunit 2B. Proc Natl Acad Sci USA 91:3954-3958.

Mori H, Mishina M (1995) Structure and function of the NMDA receptor channel. Neuropharmacology 34:1219-1237.

Moriyoshi K, Masu M, Ishii T, Shigemoto R, Mizuno N, Nakanishi S (1991) Molecular cloning and characterization of the rat NMDA receptor. Nature 354:31-37.

Niethammer M, Kim E, Sheng M (1996) Interaction between the C terminus of NMDA receptor subunits and multiple members of the PSD-95 family of membrane-associated guanylate kinases. J Neurosci 16:2157-2163.

Nikolic B, Mac Nulty E, Mir B, Wiche G (1996) Basic amino acid residue cluster within nuclear targeting sequence motif is essential for cytoplasmic plectin-vimentin network junctions. J Cell Biol 134:1455-1467.

Paoletti P, Ascher P (1994) Mechanosensitivity of NMDA receptors in cultured mouse central neurons. Neuron 13:645-655.

Pardo JV, Siliciano JD, Craig SW (1983) A vinculin-containing cortical lattice in skeletal muscle: transverse lattice elements ("costameres") mark sites of attachment between myofibrils and sarcolemma. Proc Natl Acad Sci USA 80:1008-1012.

Peters A, Palay SL, Webster HD (1991) The fine structure of the nervous system: the neurons and supporting cells. New York: Oxford UP.

Petralia RS, Wang YX, Wenthold RJ (1994a) Histological and ultrastructural localization of the kainate receptor subunits, KA2 and GluR6/7, in the rat nervous system using selective antipeptide antibodies. J Comp Neurol 349:85-110.
Petralia RS, Yokotani N, Wenthold RJ (1994b) Light and electron microscope distribution of the NMDA receptor subunit NMDAR1 in the rat nervous system using a selective anti-peptide antibody. J Neurosci 14:667-696.

Phillips WD, Kopta C, Blount P, Gardner PD, Steinbach JH, Merlie JP (1991) ACh receptor-rich membrane domains organized in fibroblasts by recombinant 43 -kilodalton protein. Science 251:568-570.

Rosenmund C, Westbrook GL (1993) Calcium-induced actin depolymerization reduces NMDA channel activity. Neuron 10:805-814.

Sealock R, Murnane AA, Paulin D, Froehner SC (1989) Immunochemical identification of desmin in Torpedo postsynaptic membranes and at the rat neuromuscular junction. Synapse 3:315-324.

Seeburg PH (1993) The TINS/TIPS Lecture. The molecular biology of mammalian glutamate receptor channels. Trends Neurosci 16:359-365.

Small JV, Sobieszek A (1977) Studies on the function and composition of the 10-NM(100-A) filaments of vertebrate smooth muscle. J Cell Sci 23:243-268.

Small JV, Furst DO, De Mey J (1986) Localization of filamin in smooth muscle. J Cell Biol 102:210-220.

Small JV, Furst DO, Thornell LE (1992) The cytoskeletal lattice of muscle cells. Eur J Biochem 208:559-572.

Stappenbeck TS, Green KJ (1992) The desmoplakin carboxyl terminus coaligns with and specifically disrupts intermediate filament networks when expressed in cultured cells. J Cell Biol 116:1197-1209.

Stappenbeck TS, Bornslaeger EA, Corcoran CM, Luu HH, Virata ML, Green KJ (1993) Functional analysis of desmoplakin domains: specification of the interaction with keratin versus vimentin intermediate filament networks. J Cell Biol 123:691-705.

Sugihara H, Moriyoshi K, Ishii T, Masu M, Nakanishi S (1992) Structures and properties of seven isoforms of the NMDA receptor generated by alternative splicing. Biochem Biophys Res Commun 185:826-832.

Tingley WG, Roche KW, Thompson AK, Huganir RL (1993) Regulation of NMDA receptor phosphorylation by alternative splicing of the C-terminal domain. Nature 364:70-73.

Tingley WG, Ehlers MD, Kameyama K, Doherty C, Ptak JB, Riley CT, Huganir RL (1997) Characterization of protein kinase A and protein kinase $\mathrm{C}$ phosphorylation of the $N$-methyl-D-aspartate receptor NR1 subunit using phosphorylation site-specific antibodies. J Biol Chem 272:5157-5166.

Traynelis SF, Hartley M, Heinemann SF (1995) Control of proton sensitivity of the NMDA receptor by RNA splicing and polyamines. Science 268:873-876.

Troyanovsky SM, Troyanovsky RB, Eshkind LG, Leube RE, Franke WW (1994) Identification of amino acid sequence motifs in desmocollin, a desmosomal glycoprotein, that are required for plakoglobin binding and plaque formation. Proc Natl Acad Sci USA 91:10790-10794.

Walsh MJ, Kuruc N (1992) The postsynaptic density: constituent and associated proteins characterized by electrophoresis, immunoblotting, and peptide sequencing. J Neurochem 59:667-678.

Wyszynski M, Lin J, Rao A, Nigh E, Beggs AH, Craig AM, Sheng M (1997) Competitive binding of alpha-actinin and calmodulin to the NMDA receptor. Nature 385:439-442. 